\title{
Education and Learning in Second Language Contexts: Language and Diagnostic Assessment of Diverse Learners in Portuguese Schools
}

By Sandra Andrade Figueiredo, Margarida Alves Martins and Carlos Fernandes da Silva. Published by The International Journal of Diversity in Education

\begin{tabular}{lll} 
Format & Price & \\
\hline Article: Print & \$US10.00 & Order \\
\hline Article: Electronic & \$US5.00 & Order \\
& &
\end{tabular}

Research in second language assessment has highlighted comprehensive diagnostic procedures to ensure indicators that provide classification about proficiency levels in the second language. Proficiency concerns the academic skills of writing, reading, and speaking and oral comprehension, as well as interpersonal skills. Those academic competencies have different evaluation structures concerning the non-native speakers attending to their immigrant experience. Assessments developed in this area present several tests to ensure a complete classification for placement at school levels. In Portuguese schools, context diagnostics and placement are still insufficient to determine proficiency in the cognitive academic level. During this new research, young immigrant students will be evaluated trough specific tests based on international batteries applied in the second language domain. The tests are in the adaptation phase. Researchers will discuss the main criteria that should be considered including language conventionality, complexity of texts, knowledge demands, type of lexicon on words list, verbal analogy, and scoring format (criteria such as Relative Proficiency Index and Rasch method). Our focus vill be on the evaluation of cognitive academic language proficiency to provide indicators and data regarding the structure of tests, the scoring applied, and the standards designed for proficiency levels and placement.

The online presentation is available here: $\mathrm{http}: / / \mathrm{w} w \mathrm{w}$.youtube.com/watch?v=4tcWOj7xBq4\&feature=youtu.be" >

Keywords: Second Language, Immigrant Students, Schools Diversity

The International Journal of Diversity in Education, Volume 13, Issue 1, November 2013, pp.31-40. Article: Print (Spiral Bound). Article: Flantrnnir (DNF File. 2 AnQMaR) 